\title{
A comparative study of interlocking directorates at the end of the import-substituting industrialization period in Argentina and Chile ${ }^{1}$
}

\author{
Erica Salvaj- Universidad del Desarrollo. Chile ${ }^{2}$ \\ Andrea Lluch- CONICET. Argentina ${ }^{3}$
}

\begin{abstract}
Research on interlocking directorates has been conducted primarily in the United States and European countries. Little work of either theoretical or empirical nature has been done to study the characteristics and the factors that affect this important business network in peripheral and turbulent economies. In this comparative and historical study, we focus on the effect of the political and economic turbulence and the ownership composition of the largest firms on shaping the structure of interlocking directorates in Argentina and Chile by the end of the sixties. Four main findings result from this analysis: 1) the interlocking directorate in Argentina is more fragmented than in Chile; 2 ) most relevant actors in the directorship interlock in Argentina are firms in industries considered strategic by the government; 3 ) multinational subsidiaries occupy a central position in Argentina; 4) banks and firms owned by local business groups played a central role in the interlocking directorates in Chile. This study shows how the institutional and economic factors shape the structure of relations between companies.
\end{abstract}

Keywords: Political and economic turbulence, interlocking directorates, Companies from Argentina and Chile

\section{Resumen}

La investigación sobre redes de directorios se ha llevado a cabo principalmente en los Estados Unidos y los países europeos. Escasos son los trabajos de investigación, ya sea de la naturaleza teórica o empírica, que han estudiado las características y los factores que afectan a esta importante red inter empresarial en economías periféricas y turbulentas. En este estudio comparativo e histórico, nos centramos en el efecto de la turbulencia política y económica y la composición de la propiedad de las empresas más importantes en la configuración de la estructura de las redes de directorios en Argentina y Chile a finales de los años sesenta. Las principales conclusiones de este análisis son las siguientes: 1) las redes de directorio son mas fragmentadas en Argentina que en Chile, 2) la mayoría de los actores mas relevantes en la red argentina son empresas de sectores considerados estratégicos por el gobierno, 3) las filiales de multinacionales ocupan una posición central en Argentina, y 4) los bancos y las empresas de propiedad de grupos de negocios locales jugaron un papel central en la red de directorios chilena. Este estudio muestra cómo los factores institucionales y económicos afectan la estructura de relaciones entre empresas.

Palabras clave: Turbulencia política y económica, redes de directorios, empresas de Argentina y Chile

\footnotetext{
1 We would like to acknowledge the generous funding from the Chilean Government Research Grant Fondecyt 11085048, entitled "Dynamics in the Chilean System of Corporate Governance. An Empiricial Study on the evolution of corporate networks in Chile from 1968 to 2006".

2 E-mail: esalvaj@udd.cl

3 E-mail: alluch@conicet.gov.ar
} 


\section{Introduction}

In many countries around the world, board networking started in the late $19^{\text {th }}$ century as a means to coordinate and organize business operations. Since then, interlocking directorates (IDs) -created when two companies share a common director- have been under the intense scrutiny of scholars and policy planning groups (Mizruchi, 1996; Hambrick, Werder \& Zajac, 2008).

IDs provide social capital to companies (Windolf, 2008; Haynes \& Hillman, 2010) and have been associated with several types of organizational outcomes. Interlocking directorates enable information transfers, mitigating opportunistic behavior (Mizruchi, 1996). Additionally, board networks build board differentiation (Podolny, 2001), affecting companies' legitimacy and reputation (Davis \& Robbins, 2004; Kang, 2008; Rhee \& Valdez, 2009; Bucheli \& Salvaj, 2012). IDs have been related to firm's performance. For instance, Silva, Majluf \& Paredes (2006) have proven that family and board networks bear a positive impact on Chilean companies' results when voting share concentration is low and controlling stockholders' voting rights match their economic rights.

IDs have also been used as control mechanisms across companies (Pfeffer \& Salancik, 1978). For example, business groups in Chile and Argentina use IDs extensively to control and drive information flows across their companies (Khana \& Rivkin, 2006; Lluch, Salvaj \& Barbero, 2011). Finally, these networks may also be used to build ties with local governments (Lester, Hillman, Zardkoohi \& Canella, 2008). For instance, in Chile, Spanish multinationals' subsidiaries tend to rely on more than other companies- directors with close ties to the government (Bucheli \& Salvaj, 2009).

As a result, studying this sort of ties proves very useful to understand how crossorganizational relationships are set up and how a country's economy is organized. In recent decades, researchers have applied sophisticated network analysis methods to examine board social capital and to map ID structure in multiple country environments (Stokman, Ziegler \& Scott, 1985; Windolf, 2002; Corrado \& Zollo, 2006). However, most theoretical and empirical studies on corporate network structure have been conducted in countries with stable institutional environments (e.g., the United States and Europe) and are primarily based on public companies (Windolf, 2002; Davis, Yoo \& Baker, 2003; Salvaj \& Ferraro, 2005; Corrado \& Zollo, 2006). 
Thus, considering the many forms interlocking directorates have adopted (Granovetter, 1993; Rinaldi \& Vasta, 2005), these practices should be analyzed in multiple, formerly neglected settings. This research study intends to fill this gap in the literature, exploring these practices in Argentina and Chile in order to illustrate the fact that two countries with a similar type of capitalism can have very dissimilar interlocking directorates structures.

Following this last proposition, and based on a sample of 165 Chilean firms and 116 Argentine companies, we argue that differences in institutional environments and largest firms' ownership structure affected ID schemes in both countries by the end of the 1960s. Four key findings are presented here: 1) Argentina's interlocking directorates are more fragmented than in Chile; 2) in Argentina, the most relevant business actors in directorship interlocks are firms in industries viewed as strategic by the government; 3) multinational subsidiaries hold a central position in Argentina's corporate network; 4) banks and firms owned by local business groups have played a leading role in Chile's interlocking directorates.

The article has been organized as follows. The section below describes corporate board systems in Argentina and Chile, providing an explanation of boards' links as well. The second section explores the differences in institutional and economic environment separating Chile and Argentina, taking a look at largest firms' ownership composition and its impact on interlocking directorates. The third section discusses the role played by several types of companies in interlocking directorates, using network centrality measurements. Finally, the last section summarizes findings and conclusions.

\section{The board of directors and the interlocking directorates}

The board of directors ranks among the most important institutions in the national corporate governance system. In the late 1960s, while Chile employed a simple directorship system, companies in Argentina were able to divide competencies between their board and an executive or management committee (consisting of some directors). However, as this scheme was not mandatory, few companies actually applied this system, hindering Argentina's categorization as a country using the Latin system (Stokman et al 1985). The Latin system featured a two-board scheme, with separate auditing and administrative boards. It was only in 1972 that Act 19,550 provisioned the existence of an Oversight Council, but it was (and continues to be) optional. At this time, syndics, who represented shareholders, audited Argentine corporations. It was the syndic's responsibility to examine the corporation's books and to review its financial statements, annual reports, and matters relating to its compliance with local laws. Also, the syndic represented all 
company shareholders on the board of directors and was thus legally provided with more power than other members of the board. This position was also usually reserved for certified public accountants and financial advisers and did not necessarily come with an interest in the company (Tokman, 1973).

Board members were appointed at shareholders' meetings and entrusted with the immediate management of corporate businesses. At that time, neither Argentine nor Chilean laws required a specific number of board members. Board tasks included business management, property administration, and personnel governance. Board members also shared unlimited liability for their managerial decisions and for compliance with current laws, by-laws and shareholder meetings' decisions.

Companies often invited reputable members of the local business community and trusted executives to join their boards, and these individuals could serve at several boards at the same time. These directors who simultaneously sat at more than one board built interlocking directorates (Mizruchi, 1996). As noted earlier, an ample body of literature has analyzed board networks from a historical point of view as an "important institution of emerging organized capitalism" that did not replace the market but performed significant -and changing- roles in the late $19^{\text {th }}$ century's capitalistic economies. Windolf (2008) argues that the appearance of large public companies destroyed the organizational basis of the corporate world dominated by family networks and enterprises. Corporate networks -mostly emancipated from ascriptive relations as family or ownership- emerged as a new institution for coordinating business transactions that grew more professional and legally regulated also in the late $19^{\text {th }}$ century, as reported by Windolf $(2008)$, Useem (1984) and Koenig, Gogel, and Sonquist (1979), it became professionalized and legally regulated.

\section{Institutional Setting and Organizational Scheme}

\section{Environmental turbulence: Political and economic setting}

The "resource dependence" theory claims that environmental turbulence affects interlocking directorates usefulness (Carpenter and Westphal, 2001; Shropshire, 2010). By environmental turbulence, we refer to the external complexity and uncertainty companies face (Boyd, 1990). Environmental turbulence is characterized, in our study, by political and economic volatility, non-cohesive local business communities, struggles between corporate groups with conflicting economic interests, armed forces' intervention, as well as political and ideological polarization. 
While Chile and Argentina share some common traits, the turbulence in their economic and institutional settings differed during the period studied here. As a result of the severe impact by the Great Depression, starting in the 1930s, both countries similarly shifted towards development strategies associated with industrialization and import substitution (ISI) policies (Ardanaz, Scartascini \& Tommasi, 2010). Their ISI models rested on two main pillars: a closed economy (high tariff barriers, quotas and exchange controls) and a strong role of the State (government expenditure as a large share of GDP, extensive regulations, and an increasing presence of state-owned firms) (Sapelli, 2003). However, Argentine and Chilean economic growth dynamics differed. Over the second half of the 20th century, Argentina's economic performance deteriorated, and a volatile growth pattern emerged, with growth paths consistently interrupted by crises leading to GDP drops, followed by slow recovery periods, only to return to previous levels years later. On the contrary, from the mid 1930 s to the early 1970s, Chile experienced rather stable growth as opposed to Argentina's recurrent ups and downs (Fourcade-Gourinchas \& Babb, 2002).

Argentina's ISI policies led to rapid industrial sector development, but exports did not expand much, and over time this lay at the core of the economic stagnation that marked the eventual collapse of that development model in the 1970s. This period featured a remarkably continued application of the general policies associated with an ISI strategy. Nonetheless, a more radical ISI approach was rolled out after 1954, with a focus on input supplying and capital goods sectors as well as on promoting industrial exports. In 1958-1962, the so-called "developmental" administration's economic program revisited the notion of accelerating by boosting investments, concentrating on a few capital-intensive and import-substitution sectors (Barbero \& Rocchi, 2003). Later, Onganía's military regime (1966-1970) also fostered industrialization. First, the relation between internal and external prices was distorted to protect Argentina's manufacturing sector. Second, a complex investment incentive scheme was created to promote the local industry, and a "buy national" program was launched (Acuña, Galiani \& Tommasi, 2006). Third, direct government investments in industries viewed as strategic -namely, iron and steel, petrochemical, and paper and pulp also promoted industrialization. Fourth, the government extended financial facilities through BIRA/BANADE (state-owned banks) loans.

Chile's economic policy also was characterized by the application of ISI strategies, even if Alessandri's government (1958-1964) -a conservative party leader and businessman- made some attempts at liberalization moves. These steps helped stabilize inflation and encouraged economic growth while drawing the country 
partially away from an inward-looking industrial development strategy. However, many of these liberalization policies were short-lived. Growing imports and increased government spending on public works and housing resulted in a trade imbalance and an overvalued currency. Starting in 1962, a balance-of-payments crisis led to a "peso" devaluation and the restoration of trade protectionism (Kline, 1992).

Frei Montalva's administration promoted a mixed economy, with the government playing a more active role. Frei Montalva championed the so-called "Revolución en libertad" (Revolution in Freedom"), marking the onset of a copper mine expropriation process and an agrarian reform. This program sought to secure an interest for Chile (eventually 51 percent) in the ownership of the country's large copper mines, along with commitments to expand production. At that time, twothirds of the Chile's export revenues came from this industry, but most mines were owned by American companies (Kline, 1992). Despite Frei's reform plans, in the late 1960s, Chile's economy had not improved, and, between 1950 and 1970, its economic performance was the poorest among Latin America's large and mediumsized countries.

In terms of political instability, there is a clear difference between both countries. Democracy prevailed in Chile between 1932 and 1973, and only two elected presidents ruled the country in the 1960s. On the contrary, Argentina's stop-go economic cycles and the proscription of the Peronist Party from electoral competition since 1955 caused significant political instability. From 1955 to 1963, the country had five presidents -only one of them was democratically elected. In 1962, the ruling democratic president Arturo Frondizi was overthrown by another military coup. For two years, Senator Guido, a puppet of the military, served as surrogate president. The next democratically elected government was also shortlived. President Illia was elected in 1963 and ousted by a military coup in 1966. Since then, three generals alternated in office. Social turmoil and growing political violence unrest forced Onganía to resign in 1970 (Bozzoli, della Paolera \& Irigoin, 2003:51).

Much of Argentina's political instability boiled down to a struggle between corporate groups with conflicting economic interests, with the armed forces intervening, but not always in the same direction (Barbero \& Rocchi, 2003). The corporate elite was greatly divided through the 1960s, and the nationalistic program adopted by Ongania's regime caused more friction between the government and traditional business groups (BGs) with international connections. A clear demonstration of these conflicts arose in 1967, when the country's largest companies, including 
multinationals, withdrew from active participation in the UIA (Argentine Industrial Union), the most important business association, and created the Consejo Empresario Argentino (Argentine Business Council). At the same time, the UIA began to draw away from liberalism, shifting toward a stance more akin to economic nationalism and criticizing the "denationalization" of Argentine industry during Onganía's dictatorship (Brennan, 2007).

The 1960 s also featured increasing political and ideological polarization among several groups in Argentina and Chile (Solimano, 2004). Starting in the mid 1960s, Argentina experienced an earlier and shocking rise in political violence. Gradually, this violence became normal, and, in a certain way, it was accepted by much of society, even as a legitimate means to settle conflicts (Romero, 2009). A complex political juncture, characterized by a deterioration of institutional expression channels, paved the way for the emergence of left-wing guerrilla organizations. ${ }^{4}$ In Argentina, unlike what happened in Chile, guerrilla groups that kidnapped prominent businessmen, demanding hefty ransoms, especially targeted foreign companies and executives. It is difficult to assess the impact of such activities before 1973. However, in 1965, there were fewer than ten incidents per month, while, by June 1976, before the last military coup, over 300 incidents were reported every month (Holmes, 2001). Time Magazine estimated that 60 percent of foreign businessmen left Argentina in 1973, prompted by the kidnapping of 170 managers that year (Gillespie, 1982). Former Argentine executives have indicated that serving at boards increased public exposure and therefore the threat of kidnappings, reducing the incentives to join them. Indeed, violence against businessmen may have undermined incentives for corporate elite members to participate as directors and the creation of links among companies, adding a new element to the uncertain scenario described earlier (Boyd, 1990).

Chile's business environment was somewhat different in the same period. Chilean businessmen, together with major corporate associations, exerted a stronger influence on public policies than their Argentine counterparts, and their leverage was strengthened by the smaller size and geographic concentration of Chile's business elite (Zeitlin \& Ratcliff, 1988; Ross Schneider, 2004). Alessandri Rodriguez's administration held close ties to local business interests, guaranteeing a continuation of policies favoring less state intervention and regulation (Kline, 1992).

\footnotetext{
4 Two of the most important groups were the Peronist Montoneros and the Trotskyite Revolutionary People's Army (ERP) (Skidmore \& Smith 2001). In Chile, the MIR (Revolutionary Left Movement) was founded in 1965 and went underground in 1968. It carried out armed actions from underground in an attempt to seize power through insurrection (until Salvador Allende's victory in 1970).
} 
In Argentina's volatile context of the late 1960s, firms' ability to formulate longterm strategies and outside directors' contributions to board monitoring and resource supply tasks were reduced (Carpenter \& Westphal, 2001). A more troubled and complex decision-making context made it hard for boards to receive and exploit directors' outside experience (Shropshire, 2010), which, in turn, undermined the appeal of recruiting multiple directors. Testimonies of Argentine directors who served at boards during that period indicate that some firms avoided discussing strategic issues at board meetings to retain some flexibility to respond to the country's changing political and economic setting.

Argentina's political and economic turbulence curtailed the benefits potentially afforded by interlocking directorates as well as the incentives to bring outside directors into boards. As a result, the number of links among companies dropped, hampering interlocks schemes. We argue that, while both countries were immersed in turbulent settings, Chile's business environment, characterized by a more serene coexistence, allowed for the survival of corporate links. Instead, Argentine corporate elite's ideological division, social dissolution and violent atmosphere may have reduced the use of board networks among firms as a common practice and effective mechanism to achieve business unity (Mizruchi, 1996; Burris, 2005).

\section{Ownership and organizational structures}

While economic and institutional instability underlay businessmen's behavior throughout this period, economic reforms driving changes in economic elites' composition and traits in both countries also proved influential. As noted by earlier studies on other countries, businesses' organizational formats and ownership schemes also shaped ID structures (Rinaldi \& Vasta, 2005; Khana \& Rivkin, 2006; Corrado \& Zollo, 2006). For example, Rinaldi and Vasta (2005) explored interlocking directorates at Italian joint-stock companies between 1952 and 1972. They found differences between the interlocking strategies of corporations and smaller companies.

The specificities of Argentine and Chilean capitalisms and their respective ranges and forms of state intervention in the economy led, nearing the end of the ISI phase, to two different enterprise ownership schemes. Particularly noteworthy was the dissimilar share of local business groups and multinationals' subsidiaries among Argentina's and Chile's largest companies. In the early 1970s, revenue rankings featuring Argentina's 100 largest companies reveal how important business groups were as compared to other organizational forms -foreign multinationals (MNEs), state-owned companies, and stand-alone domestic private companies. By then, Argentine sales rankings showed that, among the leading 100 firms, MNEs took the 
lead (with $52.6 \%$ of overall sales), while state-owned companies and domestic private firms held similar shares (23.4\% and 24\%, respectively) (Competencia Económica magazine, 1970). This latter group included a similar share of firms belonging to business groups and stand-alone private companies. In a nutshell, until the mid 1970s, local business groups played a lesser role in Argentina than in Chile; additionally, companies owned by Argentine business groups did not rank among the country's largest firms (with the noteworthy exception of Bunge y Born group), as their counterparts did in Chile. However, a recent study by Lluch, Salvaj and Barbero (2011) has argued that business groups in Argentina tended to build relatively more board links than the largest Argentine companies.

Conversely, business groups were the predominant form of corporate structure in Chile, and most Chilean largest corporations were controlled by families (Zeitlin et al 1988). Table A1 (in Appendix) shows the controlling proprietary interest of the 37 largest corporations in Chile in 1966, revealing that local families controlled 30 of them. In addition, families were highly interrelated, as proven by the number of Chilean corporations included in table A1 that were controlled by associated families. Chile displayed a more concentrated family stock ownership, with major corporations largely controlled and managed by family networks. Some classical studies have characterized this phenomenon as the supremacy of a so-called "kinecon group," a complex unit in which economic interests and kinship bonds are inextricably intertwined (Zeitlin et al 1988). As noted by Khana and Rivkin (2006), Chilean business groups' companies have largely relied on board ties. In fact, board links point to group boundaries. Bucheli and Salvaj (2011) reported differences in the linking strategies among multinationals' subsidiaries, Chilean groups' firms, and state-owned companies in Chile's telecom industry. According to these authors, Chilean business groups were more prone to building board ties.

The fact that business groups weighed more heavily in one of these economies than in the other may be also attributed to Argentina's public policies in the 1960s, which favored foreign companies over domestic groups. The governments in this period tended to promote the inflow of foreign investment (FDI) as a development strategy. This process climaxed during Frondizi's administration (1958-1962). FDI Act 14,780 was passed in 1958, with extremely favorable terms for MNEs (Mallon \& Sourrouille, 1975). As a result, capitals began to flow in and investments grew; between 1959 and 1962 FDI totaled US\$ 500 million (Barbero \& Rocchi, 2003). Ninety percent of the newly established MNEs $-60 \%$ of which were Americanfocused on the chemical, petrochemical and oil, transport, metallurgy and electric and mechanical machinery industries (see table A2 in Appendix) (Sourrouille, Kosacoff \& Lucangeli, 1985). 
Between 1961 and 1966, FDI declined, but, as Onganía took over, there was a change in the role assigned to foreign capital. As a result, in 1967, 1968 and 1969, the value of such authorizations was US\$ 13.1 million, US\$ 31.5 million and US\$ 59.1 million, respectively (Sourrouille, 1976). In 1967-1969, FDIs concentrated primarily on short-term financing and the acquisition of existing assets.

The studies mentioned above corroborate that ownership differences point to dissimilar interlocking strategies that bear an impact on corporate network structures. According to these studies, business groups tend to build more board ties. Thus, as business groups in Chile consistently ranked among the nation's largest firms, it is our hypothesis that the share of companies linked by interlocking directorates was higher than in Argentina. We also expect that the average number of links per company was also higher in Chile than in Argentina.

Indeed, our findings confirm that institutional and economic turbulence differences as well as dissimilarities in the largest firms' ownership structures in the late 1960s led to significant differences in interlocking directorates schemes in Chile and Argentina. Based on an initial graphic analysis, ${ }^{5}$ interlocking directorates among Chile's largest companies (Figure 1) shows that the network core in Chile was bigger and denser, while Argentina's network (Figure 2) was more fragmented and dispersed, with a smaller core as well.

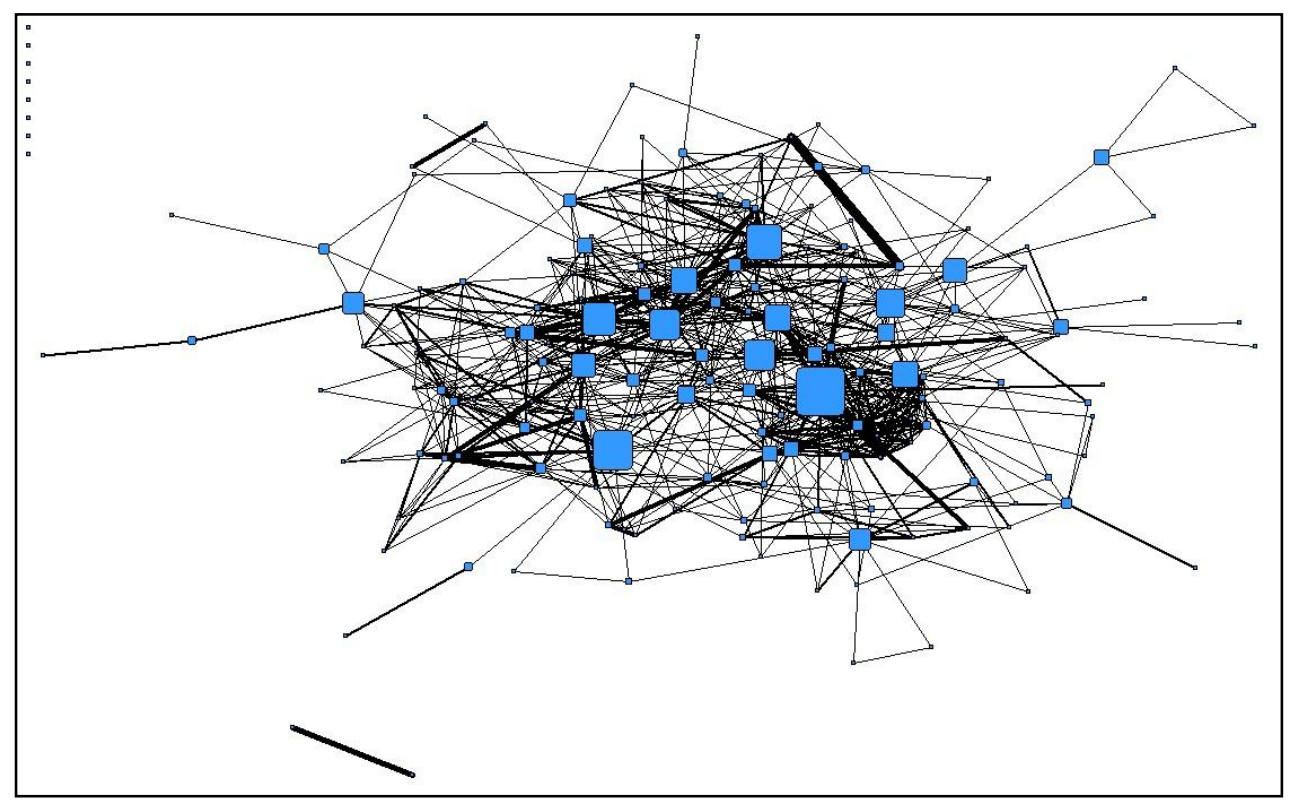

Figure 1. Interlocking directorates - Chile.

\footnotetext{
${ }^{5}$ In these figures, nodes are firms, and a tie between any two firms represents the directors both firms have in common. The width of the tie represents the number of directors shared by two firms. Node sizes vary according to betweenness centrality. The bigger the node, the more central the company is.
} 
Figure 1 shows that the number of ties among boards was remarkably greater in Chile, while Argentina's boards' network featured a lower number of lines, indicating fewer ties or shared directors. Also, Chile's network displayed dense cliques, signaling a larger number of lines joining companies that belonged to the same business group. As a result of the small number of companies belonging to the same business group in Argentina's directorate interlocking network, such dense cliques are not found in Figure 2.

The larger nodes in Figure 1 represent firms and banks owned by Chilean business groups (see Table 2 for betweenness centrality). Instead, in Figure 2, the two largest nodes represent multinationals' subsidiaries (see Table 2).

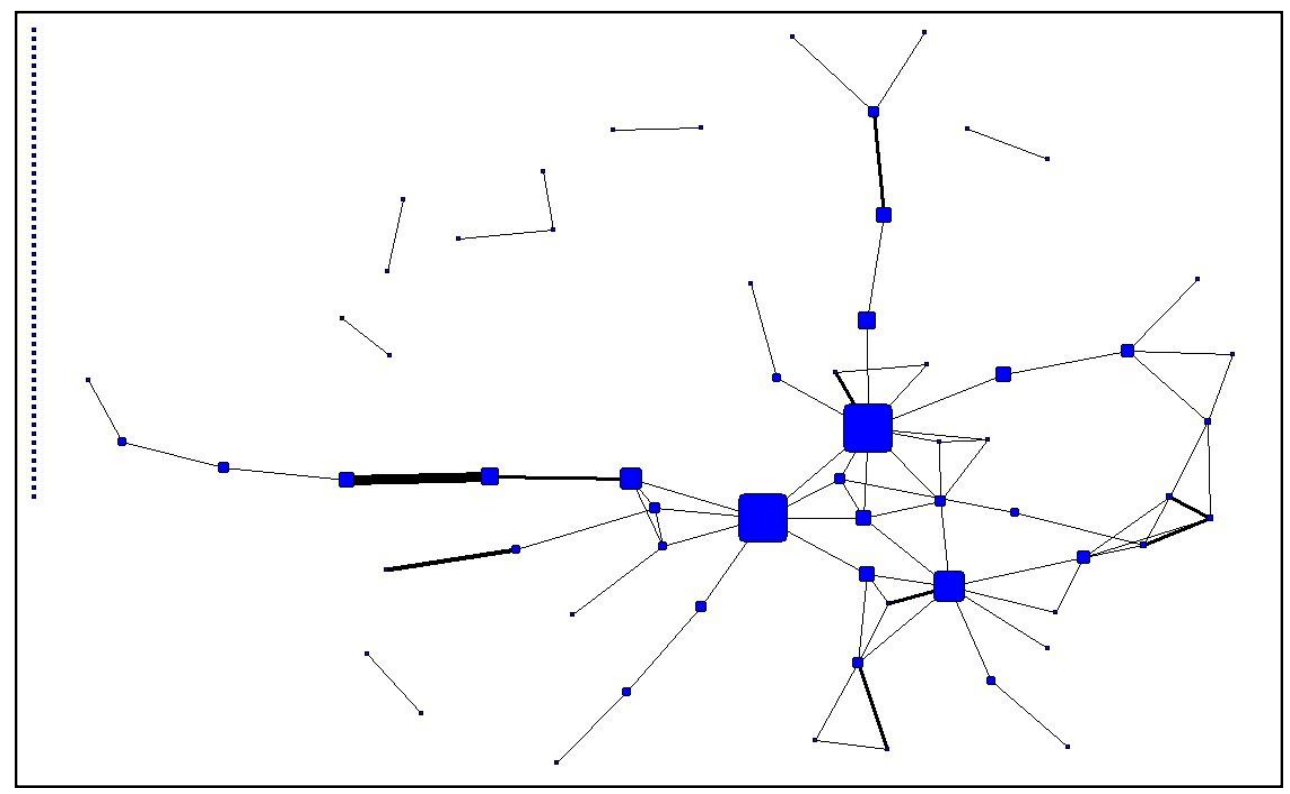

Figure 2. Interlocking Directorates - Argentina.

These graphic results are corroborated by the structural parameters found in Table 1. Our total sample contains 116 Argentine firms and 165 Chilean companies (see the Appendix for a detailed description of data sources, and Table A3 for a list of all firms classified by industry and ownership scheme).

Line 4 (see Table 1 ) shows the number of financial companies. Argentina's 33 financial companies had 272 directors, while Chile's 25 financial firms appointed 211 directors (see line 5). Line 6 shows that the Argentine system featured more directors (861) than its Chilean counterpart (588), despite the facts that Argentina's company sample is smaller and that, on average, Argentina had smaller boards (8) than Chile (9) (See line 7).

Lines 8 and 9 record the number and percentage of connected and isolated firms, respectively. While the percentage of isolated firms in Argentina was $46 \%$, it was 
only $6 \%$ in Chile, indicating that Argentina's network was more fragmented and dispersed. The number of marginal firms (with only one or two ties) and isolated companies (no ties) was also higher in Argentina than in Chile (see lines 10 and 11), underscoring our previous argument of a more fragmented corporate elite in Argentina and a more cohesive one in Chile.

The number of firms in the main component (which only includes the firms that share board members; firms with no interlocks are excluded) or the network core is reported in line 12. As shown, Argentina's network core only included $43 \%$ of all firms, while nearly all Chilean firms, 94\%, took part in their country's network core. Line 13 shows the number of companies remaining in the network once lower-than2 ties (sharing fewer than two directors -this procedure is known as 2 m-slices) are removed. In Argentina, only 16 companies remain in the network when these ties are removed, while this number rises to 97 in Chile. Once again, this proves Argentina's network was much more fragmented than its Chilean counterpart.

We also compared the number of ties and density of the Argentine and Chilean networks as well as their main components (see lines 14 to 16). Argentina featured 81 lines, while Chile boasted 755. Of the total set of possible connections among Argentine firms, $6 \%$ occurred within the network core (or main component); considering all ties, the density increased to $7.2 \%$. In Chile, these percentages were $5.6 \%$ and $8.1 \%$, respectively.

Considering indirect ties or networks' communication structure, we have to look at the diameter and average distance between reachable pairs of firms. Both diameter (the longest geodesics of the network -i.e., the length of the path between the two most distant nodes) and average distance were higher in Argentina than in Chile, signaling the lower network cohesiveness of Argentina's corporate elite (see lines 17 and 18).

The average degree of both network and main component is higher in Chile than in Argentina (see lines 19 and 20 in Table 1). Average degree is a better measure of overall cohesion than density, as it does not depend on network size; thus, average degree can be compared between networks of different sizes. While Argentina's network average degree stood at 1.6, Chile's was 11.5. Chilean firms relied on interlocks more heavily as a tool of coordination and control. 


\begin{tabular}{|c|l|c|c|}
\hline \multicolumn{1}{|c|}{ Country } & \multicolumn{1}{|c|}{ Yrgentina } & Chile \\
\hline & \multicolumn{1}{|c|}{} & 1970 & 1970 \\
\hline 1 & Total sample & 116 & 165 \\
\hline 2 & Number of non-financial firms & 83 & 140 \\
\hline 3 & Total number of persons & 589 & 377 \\
\hline 4 & Number of financial firms & 33 & 25 \\
\hline 5 & Total number of persons & 272 & 211 \\
\hline 6 & $\begin{array}{l}\text { Total number of directors in financial and industrial } \\
\text { firms }\end{array}$ & 861 & 588 \\
\hline 7 & Average board size (number of board members) & 8 & 9 \\
\hline 8 & Number and percentage of connected firms & $63(54 \%)$ & $157(95 \%)$ \\
\hline 9 & Number and percentage of isolated firms & $52(46 \%)$ & $8(6 \%)$ \\
\hline 10 & Number and percentage of marginal firms & $35(30 \%)$ & $25(15 \%)$ \\
\hline 11 & $\begin{array}{l}\text { Isolated and marginal firms as \% of total number of } \\
\text { firms }\end{array}$ & $76 \%$ & $20 \%$ \\
\hline 12 & $\%$ of firms in main component & $50(43 \%)$ & $155(94 \%)$ \\
\hline 13 & Number of firms in 2m-slices & $16(14 \%)$ & $97(59 \%)$ \\
\hline 14 & Total number of lines & 81 & 755 \\
\hline 15 & Density (main component - dichotomized) & $6 \%(74$ lines) & $5.6 \%(755$ \\
\hline 16 & Density (main component) & $7.2 \%$ & $8.1 \%$ \\
\hline 17 & Diameter & 11 & 7 \\
\hline 18 & Average distance to main component & 4.269 & 2.838 \\
\hline 19 & Network average degree & 1.638 & 11.539 \\
\hline 20 & Main component average degree & 2.96 & 12.232 \\
\hline 21 & Number of interlockers & 63 & 159 \\
\hline 22 & Number of big linkers & 11 & 74 \\
\hline 23 & Interlockers as \% of directors & $1 \%$ & $13 \%$ \\
\hline 24 & Big linkers as \% of directors & & \\
\hline & & $7 \%$ & $13 \%$ \\
\hline
\end{tabular}

Table 1. Structural parameters.

Interlockers (directors who hold two or more positions in the network) and big linkers (directors who hold three or more positions in the network) point to network redundancy (see lines 21 to 24). As the number of companies in the sample is higher in Chile, the percentage of multiple directors is smaller in Argentina (7\%) than in Chile (27\%), as line 23 indicates. Chilean network's greater redundancy provided more opportunities to exercise control.

In short, Table 1 findings confirm our hypothesis. While both countries pursued ISI development strategies and faced social and economic turbulence in the late 1960s, Argentina experienced a more unstable economic environment, with more political turmoil and a less cohesive business community than Chile. These external conditions affected Argentina's interlock network structure, reducing the average number of ties per firm and heightening fragmentation in its boards' network. In contrast, Chile's more politically stable environment (until 1970), its cohesive power elite, and greater local business group engagement contributed to the 
creation of a higher number of links among Chilean firms, producing a dense board network.

\section{Actors' centrality}

Differences separating Argentina's and Chile's interlocking directorates also bore an impact on the role played and positions held by companies in those networks. Several centrality measures provide a greater insight into the roles played by companies in both countries' board networks in the late 1960s (see Appendix for centrality measures definitions).

The role of business groups

According to the arguments detailed in the previous section and focusing on betweenness centrality, it is clear that nine out of Chile's ten most central companies belonged to domestic business groups. Chilean business groups' companies largely ranked among the nation's largest firms and actively pursued board ties. Three firms in the ranking -Compañía Cervecerías Unidas (beverages), Chilena Consolidada de Seguros de Vida (insurance), and Banco Edwards- were controlled by the Edwards business group (owned by a financially and politically influential family of English origin that has played a significant role in Chilean politics, especially as owners of the most influential newspaper, El Mercurio). Empresas Copec was controlled by the Bulnes business group, the Banco Hipotecario (Mortgage Bank) business group, as well as the Castillo and Claro families. The list is completed by Cementos Bio Bio (Briones Business Group), Ganadera Tierra del Fuego (traditional families from Southern Chile), Banco de Chile (a group of minority investors), Banco Español de Chile (a bank controlled by the García and Pico families), and Banco Panamericano (Said Business Group). In Chile, only one company owned by a multinational, Compañía de Telecomunicaciones de Chile, was included in this betweenness centrality ranking. On the contrary, in Argentina, only two firms in this ranking were owned by local business groups -Loma Negra and Celulosa (the last, belonging to the so-called Grupo Fabril). 


\begin{tabular}{|c|c|c|c|c|c|c|c|}
\hline \multicolumn{4}{|c|}{ Chile } & \multicolumn{4}{|c|}{ Argentina } \\
\hline Company & \begin{tabular}{|l|} 
Bet. \\
Cent.
\end{tabular} & Industry & Owners & Company & $\begin{array}{l}\text { Bet. } \\
\text { Cent }\end{array}$ & Industry & Owners \\
\hline Cementos Bio Bio & 4.826 & Cement & $\begin{array}{l}\text { Chilean } \\
\text { Family }\end{array}$ & $\begin{array}{l}\text { Siemens } \\
\text { Argentina }\end{array}$ & 2.05 & $\begin{array}{l}\text { Electric } \\
\text { Prod. }\end{array}$ & Foreign \\
\hline $\begin{array}{c}\text { Compañía } \\
\text { Cervecerías } \\
\text { Unidas }\end{array}$ & 4.898 & Beverages & $\begin{array}{l}\text { Chilean } \\
\text { Family }\end{array}$ & $\begin{array}{c}\text { Pasa } \\
\text { Petroquímica }\end{array}$ & 2.06 & Chemical & Foreign \\
\hline $\begin{array}{c}\text { Ganadera Tierra } \\
\text { del Fuego }\end{array}$ & 5.033 & Agribusiness & $\begin{array}{l}\text { Chilean } \\
\text { Family }\end{array}$ & Duperial & 2.11 & Chemical & Foreign \\
\hline Empresas Copec & 5.709 & $\begin{array}{c}\text { Forestry/ } \\
\text { Petroleum }\end{array}$ & $\begin{array}{l}\text { Chilean } \\
\text { Family }\end{array}$ & \begin{tabular}{|l|} 
Bco Nacional \\
del Desarrollo
\end{tabular} & 2.11 & Banking & State \\
\hline $\begin{array}{c}\text { Chilena } \\
\text { Consolidada de } \\
\text { Seguros de Vida }\end{array}$ & 5.932 & Insurance & $\begin{array}{l}\text { Chilean } \\
\text { Family }\end{array}$ & $\begin{array}{c}\text { Bco. Popular } \\
\text { de Quilmes }\end{array}$ & 2.75 & Banking & Argentine \\
\hline $\begin{array}{l}\text { Cia. Telecom. de } \\
\text { Chile }\end{array}$ & 5.955 & Telecom & Foreign & Electrolor & 2.75 & Chemical & $\begin{array}{c}\text { Argentine/Fore } \\
\text { ign }\end{array}$ \\
\hline Banco de Chile & 6.537 & Banking & Chilean & $\begin{array}{c}\text { Celulosa } \\
\text { Argentina }\end{array}$ & 3.36 & $\begin{array}{l}\text { Paper/ } \\
\text { Forestry }\end{array}$ & Argentine \\
\hline Banco Edwards & 7.090 & Banking & $\begin{array}{l}\text { Chilean } \\
\text { Family }\end{array}$ & Loma Negra & 5.13 & Cement & $\begin{array}{l}\text { Argentine } \\
\text { Family }\end{array}$ \\
\hline $\begin{array}{l}\text { Bco. Español de } \\
\text { Chile }\end{array}$ & 7.969 & Banking & $\begin{array}{l}\text { Chilean } \\
\text { Family }\end{array}$ & $\begin{array}{c}\text { Cristalerias } \\
\text { Rigolleau }\end{array}$ & 8.41 & $\begin{array}{c}\text { Glass \& } \\
\text { Packaging }\end{array}$ & Foreign \\
\hline $\begin{array}{c}\text { Bco } \\
\text { Panamericano }\end{array}$ & 10.094 & Banking & $\begin{array}{l}\text { Chilean } \\
\text { Family }\end{array}$ & Minera Aguilar & 8.53 & Mining & Foreign \\
\hline
\end{tabular}

Table 2. Top Boards by betweenness centrality.

We additionally ran a Mann Whitney test, excluding firms without interlocks -the final sample included 50 Argentine firms and 155 Chilean firms. First, we sought to establish any centrality differences among business groups' and family-owned firms and companies that did not belong to either business groups or families in both Chile and Argentina. The results are depicted on Table 3. Once again, our findings indicated that Chilean business groups' firms and family-owned businesses were significantly more central (across all centrality measures) than their counterparts in Argentina. 


\begin{tabular}{|c|c|c|c|c|c|c|c|c|c|c|c|c|}
\hline & \multicolumn{4}{|c|}{$\begin{array}{l}\text { Companies owned by } \\
\text { business groups/families }\end{array}$} & \multicolumn{4}{|c|}{$\begin{array}{l}\text { Foreign ownership and } \\
\text { local firms }\end{array}$} & \multicolumn{4}{|c|}{$\begin{array}{l}\text { Financial and non-financial } \\
\text { institutions }\end{array}$} \\
\hline & \multicolumn{2}{|c|}{ Chile } & \multicolumn{2}{|c|}{ Argentina } & \multicolumn{2}{|c|}{ Chile } & \multicolumn{2}{|c|}{ Argentina } & \multicolumn{2}{|c|}{ Chile } & \multicolumn{2}{|c|}{ Argentina } \\
\hline & Main C & omponent & $\begin{array}{r}\mathrm{M} \\
\text { comp }\end{array}$ & $\begin{array}{l}\text { in } \\
\text { onent }\end{array}$ & $\begin{array}{r}M a \\
\text { comp }\end{array}$ & $\begin{array}{l}\text { in } \\
\text { onent }\end{array}$ & $\begin{array}{r}\mathrm{Ma} \\
\text { comp }\end{array}$ & ent & $\begin{array}{r}M \\
\text { comp }\end{array}$ & $\begin{array}{l}\text { in } \\
\text { onent }\end{array}$ & $\begin{array}{r}\mathrm{Ma} \\
\text { comp }\end{array}$ & $\begin{array}{l}\text { ain } \\
\text { onent }\end{array}$ \\
\hline ariable & $\begin{array}{l}\text { Z- } \\
\text { score }\end{array}$ & Sig. & $\begin{array}{c}\text { Z- } \\
\text { score }\end{array}$ & Sig. & $\begin{array}{c}\text { Z- } \\
\text { score }\end{array}$ & Sig. & $\begin{array}{c}\text { Z- } \\
\text { score }\end{array}$ & Sig. & $\begin{array}{c}\text { Z- } \\
\text { score }\end{array}$ & Sig. & $\begin{array}{c}\text { Z- } \\
\text { score }\end{array}$ & Sig. \\
\hline e & -3.2 & & 287 & $\begin{array}{r}0.774 \\
2\end{array}$ & 387 & $\begin{array}{r}0.165 \\
5\end{array}$ & 0.594 & $\begin{array}{r}0.552 \\
5\end{array}$ & 1.524 & & 1.628 & 0.103 \\
\hline $\begin{array}{l}\text { etw } \\
\text { ss }\end{array}$ & 1.842 & $.0655 *$ & 1.234 & $\begin{array}{r}0.217 \\
3\end{array}$ & 1.324 & $\begin{array}{r}0.185 \\
4\end{array}$ & -0.28 & $\begin{array}{r}0.779 \\
7\end{array}$ & 3.335 & $\begin{array}{r}0.0009 \\
* *\end{array}$ & 0.06 & 0.951 \\
\hline Eigenvect & -3.372 & $0.0007 * *$ & 0.574 & $\begin{array}{r}0.566 \\
2\end{array}$ & 1.559 & 0.119 & \begin{tabular}{|r|} 
\\
1.213 \\
\end{tabular} & 0.225 & -0.51 & 0.6104 & 1.453 & 0.146 \\
\hline of firms & 155 & & 50 & & 155 & & 50 & & 155 & & 50 & \\
\hline
\end{tabular}

+ significant at $10 \%$ level, $*$ significant at $5 \%$ level, $* *$ significant at $1 \%$ level

Table 3. Mann Whitney test

\section{The role of Multinationals}

As mentioned earlier, MNEs played a more decisive role in Argentina's industrial development during the ISI period than they did in Chile. As a result of the policies to promote foreign direct investment, foreign firms weighed more heavily in the local economy. Among Argentina's 100 largest companies, foreign firms posted $63.3 \%$ of all sales in 1957, 76.6\% in 1962 and $79.4 \%$ in 1969 (Khavisse \& Piotrkowski, 1973). Foreign companies, particularly the larger ones, operated in highly concentrated markets, with just a few players, where Argentine private enterprises' engagement was only secondary (at least until 1970) (Azpiazu \& Kosacoff, 1985).

Instead, in Chile, FDI seized control over the most important mining activities. In the 20th century, up to $90 \%$ of FDI concentrated in Chile's mining operations, focusing primarily in copper. Foreign firms also invested in electrical utilities and telephone services, but, despite the relative growth of some industrial investments, MNEs did not dominate the country's light manufacturing sector. Chile's natural resources explain much of this pattern, since only its mineral wealth was well recognized at the time, and the country's small consumer market had but little appeal for foreign investors (Kline, 1992). As noted earlier, local BGs appear to have been more decisive than MNEs in Chile, despite the occasional foreign (mainly U.S.) pressures on local governments. While foreign and domestic business interests often coincided, especially when it come to assuring limited state intervention in the economy, when they diverged, local BGs successfully influenced several Chilean administrations to shift toward more favorable, pro-local business policies (Kline, 1992). Considering the less prevalent role of MNEs in Chile's 
industrial sector, multinational corporations were more central in Argentina than Chile by 1970 .

In fact, as Table 2 shows, six foreign owned companies ranked among the ten most central firms in Argentina, while only one foreign firm showed up in Chile's ranking. These findings also suggest that multinationals were integrated into Argentine corporate networks, ranking among the most connected firms, but they were not significantly more connected than domestic firms (see Table 3 ). This may be associated with the important role played by MNE subsidiaries in Argentina's industrial development.

This research also revealed that the level of internationalization or interconnections among Chilean and Argentine boards was very low by the late 1960s. Indeed, our findings show that only two directors, Fernando Carles and Felix Van de Walle, served at boards on both sides of the Andes. Argentine and Chilean firms sharing one director were owned by American corporations. Cristalerías Rigolleau and Cristalerías de Chile were controlled by Corning Glass, while Embotelladora Andina and Coca Cola Argentina belonged to Coca Cola, and Squibb was a subsidiary of an U.S.-based pharmaceutical company.

The role of banks

Previous research has emphasized two dominant models for the role of banks in corporate networks (Davis \& Mizruchi, 1999). The first stated, "interlocks are a means of control that allows banks to build up interest groups of firms, which are to serve the bank's interests. This power derives from their quality both as lenders and as large shareholders." The second model emphasized "reciprocal relationships between banks and industry, where coordination, not dominance, is the prevailing mode of interaction: bank - industry ties are mutual rather than directed from the former to the latter." This model depicts interlocks as an expression of cohesion within the ruling class and as a means for this unity to be maintained and furthered.

This research study shows that banks played a central role in Chile, coordinating its corporate elite -a role banks did not play in Argentina. As Table 2 shows, four banks appeared among the most central firms in Chile's network in Chile -namely, Banco Panamericano, Banco Español-Chile, Banco Edwards, and Banco de Chile. In turn, Argentina's ranking featured only two: Banco Popular de Quilmes and Banco Nacional de Desarrollo. In Argentina, the evidence proves that banks did play a less significant role as corporate network connectors. Why did banks not serve as big linkers? This may be attributed to two features: 1) companies' ownership structure (discussed earlier), and 2) Argentina's business financing scheme. Back then, 
Argentina's capital market was not a relevant source of funding for companies; in fact, its performance in this regard weakened in the 1960s, as a result of highly volatile economic conditions. Neither did private banks offer long-term loans for industries. However, the business groups that emerged in the 1960 s did not branch out into finance as much, and none of the main BGs emerging in the post WWII period was organized around a bank, although the Techint group had financial investments and other groups had extensive contacts with private banks and financial firms.

Private financing may have been scarcely relevant because companies largely sought their funding from long-term loans provided by Argentina's Banco Industrial (BIRA-1944), followed by Banco Nacional de Desarrollo (Banade-1970), and from international loans enabled by institutions like the Inter American Development Bank and the World Bank. By 1954, BIRA concentrated half of all industrial loans. Through official banks' operations, the State grew its interest in the economy, not only as a loan provider but also as a manager of state-owned and private companies. The State's increased interest in private firms' equity came as a result of weaknesses in companies' structures, especially in financial firms (Rougier, 2004), or, in other cases, as a result of decisions made by economic officials to drive some firms. BIRA's -and, then, BANADE's- operations were shaped by Argentina's economic and institutional instability. In 1967-1976, 11 chairmen stood at its helm, and none of the 40 directors who served at its board stayed on for three full years.

Instead, national development banks in Chile did not play the same role. In 1965, a new decree (Number 16,253) alloyed the creation of development banks. Yet, a series of restrictions were imposed, and the first bank was founded in late 1974. Since 1968, Banco Estado was authorized to operate as a development bank, but its medium and long term lending volume remained low due to the low incentives to attract long-term funds, although the demand for such loans was high (Behrens Fuchs, 1985).

In Chile, the stock market did not fully develop as a source of capital. Couyoumdjian, Millar \& Tocornal (1993) suggest that companies rarely listed their stock to raise funds from external investors. In this setting, capital markets did not play a significant role in resource allocation, and, as a result, the period from 1920 to 1970 was characterized by a steady decline of both the number of stock market transactions and the stock market's value over Chile's GDP (Islas, 2010).

Lefort \& Walker (2000a) argue that financial repression and credit rationing during a large share of the 20th century gave way to the extensive use of internal capital 
markets and the subsequent emergence of bank-centered groups in Chile. Large companies belonging to social networks had access to cheap financing trough associated banks (Lefort, 2010). Private banking was controlled by BGs that also controlled monopolistic firms in other economic sectors. For example, the Yarur Banna BG owned more than $50 \%$ of Banco de Crédito e Inversión and controlled both Banco Llanquihue and Banco Continental; Banco Nacional del Trabajo and Banco Panamericano lay at the core of another BG (with interests in the textile industry): the Said group; Banco Edwards was controlled by the namesake family. The Matte BG owned Banco Sudamericano, while Banco Israelita belonged to the Litvak Decepter family. Chile's largest private bank, Banco de Chile, was at center of intense financial fights among clans, as several BGs held an interest in it (Behrens Fuchs, 1985).

A mechanism that facilitated the control of banks by economic groups was ID. Chilean banks stood at the center of BGs, and banks' directors often served on the boards of several companies in Chile. In 1968, 52 directors of the five largest banks held 316 board seats; in 1970, a Banco de Chile director also served as a board member in 13 other corporations; and, at the same bank, every director represented at least three other companies. Our Mann Whitney test revealed significant differences in the betweenness centrality of Chilean banks. Table 3 shows that banks were more central than non-financial institutions in Chile in terms of betweenness centrality. In short, we find that banks were more central in Chilean interlocks and that private banks played an intermediation and coordination role that their counterparts in Argentina did not have.

\section{Big linkers}

A company is central when the directors sitting at its board also serve at other companies' boards, becoming multiple directors or big linkers. Who and how many were the big linkers in Chile's and Argentina's networks? Multiple directors or big linkers were more common in Chile than in Argentina (see table 1, lines 21 to 24). Table A4 (in Appendix) lists the big linkers in both countries' networks.

Chile's list was dominated by businessmen -a more classical scheme, largely discussed in current literature, with businessmen serving as "linkers," revealing shared control relationships or strategies to control other firms with common investment projects. Eliodoro Matte, the director boasting the highest betweenness centrality, served at the boards of its group's bank and several of its companies, as well as in many other companies, including Banco SudAmericano, Aceros Andes, Renta Urbana Pasaje Matte, Empresas CMPC, Empresas Industrial El Melón, Minas y Fertilizantes, Ganadera Tierra del Fuego, Forestal, Constructora y Comercializadora 
del Pacífico Sur, and ABN AMRO Chile Seguros de Vida. In Argentina, such centrality was far less common, and Enrique Roberts stood out as the Argentine director with the greatest betweenness centrality (see Table A4) -he sat at the boards of Alpargatas, Cristalerías Rigolleau, Banco Frances del Río de la Plata, and Minera Aguilar and was particularly noted for his strong ties to the banking sector. However, comparatively, Argentine businessmen were less involved in interlocking -in fact, fourteen out of twenty directors were engineers, lawyers, government officials, or certified public accountants. Thus, we argue that a common attribute shared by Argentine big linkers was their engagement in government as advisors or in other capacity, especially in military regimes and administrations favoring probusiness policies. Still, it should be noted that these individuals were largely lowprofile men in the late 1960s -a characteristic that, since then, businessmen cultivated as political violence grew.

We hypothesize that, in Argentina's troubled business environment, firms particularly MNEs- tended to choose to include well-connected legal and financial advisors and government officials in their directories, as these individuals would know how to navigate the changing conditions created by political and economic instability, powerful labor unions, regulations, different stabilization plans, and idiosyncratic credit allocation practices (Guillen 2000:367). Attorneys, engineers and accountants specialized in providing a full range of legal services and helping multinational corporations to deal with institutional barriers to. As a result, these professionals (acting as syndics) and government officials played a more important role in Argentina's elite network than their counterparts in Chile. Indeed, our findings seem to match those of Bearden and Mintz (1992:192), who note that, in the United States, outside directors (that is, board members who do not actively participate in a company's daily operations and have no significant stake in its equity) are responsible for network cohesion and unity.

\section{Conclusions}

Primarily, this study on board ties schemes in place in Argentina and Chile over the 1969-1970 years has underscored how organizational structure changes shaped ID schemes in individual countries. Second, this study has explored an area that has been largely neglected by current literature, as few authors have looked at board interlocks in countries with underdeveloped financial markets and few publicly traded companies in local corporate business structures. Additionally, it expands the focus of past literature works on how institutional settings and national business systems might influence how larger companies organize their corporate networks when dealing with environmental conditions. 
Our comparative analyses indicate the importance of two factors: environmental turbulence and, most significantly, ownership structures. Concerning the former, our results suggest that the economic and political turbulence that characterized Argentina throughout this period undermined the social capital typically provided by interlocks in more stable settings. The results reported here support the notion that a volatile environment may hinder the access to and transfer of knowledge and decrease board receptivity (Shropshire, 2010). As described, in Argentina's case, the evidence seems to corroborate that, in a politically turbulent setting, firms may be cautious to appoint executives or businessmen with strong ties to a regime, as any sudden political changes may quickly turn that asset into a liability jeopardizing firm performance. Furthermore, this study has also revealed that violence against businessmen and a fragmented corporate community may reduce directors' motivations to serve on multiple boards. As a result, network average degree and density (interpreted as an indicator of the mass of moral capital) were higher in Chile, and, therefore, so were group control and social integration (Windolf, 2008). Indeed, this study seems to confirm the theory that benefits from social ties are dependent on environmental context (Burt, 1997; Gulati and Higgins, 2003). Argentine firms, embedded in a more uncertain political and economic environment, relied less on board ties than their counterparts in Chile. Consequently, board networks in Argentina were more dispersed and fragmented than Chile's ID.

As noted earlier, ID practices were also and more crucially shaped by ownership structures (Rinaldi and Vasta 2005, Khana and Rivkin 2006). The absence of BG firms among Argentina's largest companies and the role played by state-owned banks as primary credit providers might have curtailed firms' inclination to resort to ID. On the contrary, Chilean firms seemed to rely more heavily on ID as a means to control and coordinate their operations. We have argued that Chilean BGs used ID as a specific control mechanism. For example, group managers and owners sitting on the boards of banks routinely monitored the flow of financial resources. Chilean BGs also used ID to control affiliated corporations and to integrate with other organizations. This is partially consistent with research studies in recent years. For instance, Chilean BGs' controllers tapped into a relatively small number of people in order to manage their businesses, and these individuals served exclusively at boards of corporations affiliated to their respective groups (Lefort \& Walker, 2000b; Majluf, Abarca, Rodriguez \& Fuentes, 1998; Silva, Majluf \& Paredes, 2006). Director interlocks are particularly significant for economic actors in Chile, as they collectively build BG boundaries (Khanna \& Rivkin 2006). 
This study has also shown differences between Argentina and Chile regarding the distribution of social capital among firms. Firms in industries considered strategic by Argentina's government lay at the core of its network, boasting more social capital at board level (Haynes \& Hillman 2010). Indeed, Argentina's top ten firms included several multinationals and a few local companies in strategic sectors, like Acindar, Loma Negra, Dalmine, Pasa, Siemens, Duperial, Celulosa, and Esso. In Chile, banks stood out in corporate networks as well as firms owned by domestic BGs. As a result, Chile's corporate elite connectivity required a more central role for banks and highly concentrated corporate ownership.

Finally, the findings reported here seem to indicate that a dense corporate network in Chile may have fueled an interest to strengthening inter-firm alliances, with board networks developing into a comprehensive control instrument that facilitated cooperation within a community of interest (Windolf, 2008). Our study also suggests that, while significant, Argentine board interlocking efforts may have been less widespread as a means to disseminate corporate practices and structures as well as to reduce uncertainty and to build trust among firms, pointing to the many forms adopted by ID in similar but different environmental conditions.

\section{Research limitations}

The results of this study are subject to limitations inherent to data availability. First, findings are restricted to the largest firms in Chile and Argentina. Future research efforts could examine the ID strategies of state-owned companies and other medium-sized firms controlled by BGs that did not rank among Argentina's and Chile's largest corporations in by 1970 . This study raises further questions that cannot be readily answered with current data. For example, future studies might explore the distinctive tasks performed by corporate networks and boards in either country, and it would also be useful to secure more direct evidence on how ID influenced the operations of large corporations and the behavior of corporate elites at the end of the ISI period (both Argentina and Chile adopted pro-market reforms in the mid 1970s). In particular, a long tradition of research has focused on the role of business elites, characterizing them as exclusionary (Tokman, 1973). However, recent research has suggested that greater social cohesion among community members leads to more prosperity (Marquis 2003). Future research studies might explore the effects of cohesive corporate elites in Latin America and their role in economic development. Finally, a longitudinal study would help to determine whether the differences separating Argentina and Chile are consistent over time or are associated to the specific historical period analyzed here. 


\section{References}

AAVV. (1972). El libro de las 91: las empresas monopólicas y el área social de la economía chilena, Santiago, Ed. Barco de Papel.

Acuña, C., Galiani, S. \& Tommasi, M. (2006). Understanding the Political Economy of Structural Reform: The case of Argentina. Documento de Trabajo, 91, Departamentos de Economía y de Humanidades, Universidad de San Andrés.

Ardanaz, M., Scartascini, C. \& Tommasi, M., (2010). Political Institutions, Policymaking, and Economic Policy in Latin America. Working Paper Series No. 158, Inter-American Development Bank.

Azpiazu, D. \& Kosacoff, B. (1985). Las empresas transnacionales en la Argentina, Documento de Trabajo, 16, Buenos Aires: CEPAL.

Barbero, M.I. \& Rocchi, F. (2003). Industry and Industrialization in Argentina in the Long Run: from its Origins to the 1970's. , en della Paolera, G. \& Taylor, A. (eds.), A New Economic History of Argentina, Cambridge, Cambridge University Press.

Bearden, J. \& Mintz, B. (1992). The Structure of Class Cohesion: The Corporate Network and its Dual, en Mizruchi, M., Schwartz, M. \& Granovetter, M., Intercorporate Relations: The Structural Analysis of Business (Structural Analysis in the Social Sciences), Nueva York, Cambridge University Press.

Behrens Fuchs, R. (1985). Los bancos e instituciones financieras en la historia económica de Chile. 1811-1983. Tesis doctoral, Pontificia Universidad Católica de Chile.

Bonacich, P. (1987). Power and Centrality: A Family of Measures. The American Journal of Sociology, 92 (5): 1170-1182.

Borgatti, S., Everett, M. \& Freemen, L. (2002). Ucinet for Windows: Software for Social Network Analysis. Harvard, MA: Analytic Technologies.

Boyd, B. (1990). Corporate linkages and organizational environment: A test of the resource dependence model. Strategic Management Journal, 11: 419-430.

Bozzoli, G., della Paolera, G. \& Irigoin, M. (2003). Passing the Buck: Monetary and Fiscal Policies in Argentina: 1852-2000, in della Paolera, G and Taylor, A (eds), A New Economic History of Argentina, Cambridge: Cambridge University Press.

Brennan, J. (2007). Prolegomenon to Neoliberalism: The Political Economy of Populist Argentina. Latin American Perspectives, 34: 49-66.

Bucheli, M. \& Salvaj, E. (2009), Embrace Your Enemy, Harvard Business Review, Mayo, 22-23. 
Bucheli, M. \& Salvaj, E. (2011). "Corporate Boards and Political Strategies of Multinational Corporations, Business Groups, and State-Owned Enterprises: The Telecommunications Sector in Chile, 1958-2005". Working paper.

Bucheli, M. \& Salvaj, E. (2012). "Multinational Corporations' Obsolescing Political Legitimacy: ITT in Chile, 1920-1972." Business History Review (Forthcoming)

Burris, V. (2005). Interlocking Directorates and Political Cohesion among Corporate Elites. American Journal of Sociology, 111 (1): 249-283.

Burt, R. (1997). The contingent value of social capital. Administrative Science Quarterly, 42: 339-365.

Carpenter, M. A., \& Westphal, J. D. (2001). The strategic context of external network ties: Examining the impact of director appointments on board involvement in strategic decision. Academy of Management Journal, 4 (4), 639-660.

Corrado, R. \& Zollo, M. (2006). Small worlds evolving: governance reforms, privatizations, and ownership networks in Italy. Industrial and Corporate Change 15(2): 319-352.

Couyoumdjian, R., Millar, R. \& Tocornal, J. (1993), Historia de la Bolsa de Comercio de Santiago, 1893-1993. Un siglo del mercado de valores en Chile. Santiago: Bolsa de Comercio de Santiago.

Davis, G. \& Mizruchi, M. (1999). The money center cannot hold: commercial banks in the U.S. system of corporate governance. Administrative Science Quarterly 44: 215-239.

Davis, G. \& Robbins, G. (2004). Nothing but Net? Networks and Status in Corporate Governance. In Knorr Cetina, K. and Preda, A. (eds) The Sociology of Financial Markets. Oxford, Oxford University Press: 290-311.

Davis, G. Yoo, M., \& Baker, W. (2003). The small world of the American corporate elite, 1982-2001. Strategic Organization, 1(3): 301-326.

Fourcade-Gourinchas, M. \& Babb, S. (2002). The rebirth of the liberal creed: paths to neoliberalism in four countries. American Journal of Sociology 108(3): 533-579.

Gillespie, R. (1982). Soldiers of Peron: Argentina's Montoneros. Oxford: Clarendon Press.

Granovetter, M. (1993). The nature of economic relationship, in Swedberg R. (ed.), Explorations in Economic Sociology. New York, Russell Sage Foundation.

Guía de Sociedades Anónimas, (1972). Buenos Aires: Cámara Argentina de Sociedades Anónimas. . 
Guillén, M. (2000). Business groups in emerging economies: a resource-based view. Academy of Management Journal, 43(3): 362-380.

Gulati, R. \& Higgins, M. (2003). Which ties matter when? The Contingent effects of interorganizational partnerships on IPO success. Strategic Management Journal, 24: 127-144.

Hambrick, D; Werder, A \& Zajac, E. (2008). New Directions in Corporate Governance Research. Organization Science, 19 (3): 381-385.

Haynes, K. \& Hillman, A. (2010). The effect of board capital and CEO power on strategic change. Strategic Management Journal 31: 1145-1163.

Hollander, M. \& Wolfe, D. A. (1999). Nonparametric Statistical Methods (2nd Ed.). Canada; Wiley.

Holmes J. (2001). Political Violence and Regime Change in Argentina: 1965-1976. Terrorism and Political Violence, 13, (1): 134-154.

Islas, G. (2010). Gobierno corporativo y estructura de propiedad en Chile: 18542005, en El impacto histórico de la Globalización en Argentina y Chile, Buenos Aires: Editorial Temas.

Kang, E. (2008). Director interlocks and spillover effects of reputational penalties from financial reporting fraud. Academy of Management Journal 51 (3): 537-555.

Khanna, T. \& Rivkin, J. (2006). Interorganizational ties and business group boundaries: evidence from an emerging economy. Organization Science 17(3): 333-352.

Khavisse, M. \& Piotrkowski, J. (1973), La consolidación hegemónica de los factores extranacionales. El caso de las cien empresas industriales más grandes, Buenos Aires: Sec. de Planeamiento y Acción de Gobierno.

Kline, J. (1992). Foreign Investment Strategies in Restructuring Economies. Learning from Corporate Experiences in Chile, Westport: Greenwood Publishing Group, Inc.

Koenig, T.; Gogel, R. \& Sonquist, J. (1979), Models of the Significance of Interlocking Corporate Directorates American. Journal of Economics and Sociology. 38 (2) 173-186.

Lefort, F. \& Walker, E. (2000a). The Effects of Economic and Political Shocks on Corporate Governance Systems in Chile. Abante 2(2): 183-206.

Lefort, F. \& Walker, E. (2000b). Ownership and Capital Structure of Chilean Conglomerates: Facts and Hypotheses for Governance. Abante 3(1): 3-27. 
Lefort, F. (2010). Business Groups in Chile, en Colpan, A., Hikino, T. \& Lincoln, J. (eds.), The Oxford Handbook of Business Groups, Oxford: Oxford University Press.

Lester, R., Hillman, A., Zarkhoohi, A. \& Cannella, A. (2008). A former government officials as outside directors: the role of human and social capital. Academy of Management Journal 51 (5): 999-1013.

Lluch, A., Salvaj, E. \& Barbero, M.I. (2011). Redes Corporativas y Grupos Económicos en Argentina (a fines de la etapa de Sustitución de importaciones). Working paper.

Majluf, N., Abarca, N., Rodriguez, \& Fuentes, (1998). Governance and Ownership Structure in Chilean Economic Groups. Abante 1(1): 111-139.

Mallon, R. \& Sourrouille, J. (1975). Economic policy-making in a conflict society: The Argentine case. Cambridge: Harvard University Press.

Marquis, C. (2003). The Pressure of the Past: Network Imprinting in Intercorporate Communities. Administrative Science Quarterly, 48 (4): 655-689.

Mizruchi, M. (1996). What do interlocks do? An Analysis, Critique, and Assessment of Research on Interlocking Directorates. Annual Review of Sociology 22: 271-98.

Pfeffer, J., \& Salancik, G. R. (1978). The external control of organizations: A resource dependence perspective. New York: Harper \& Row.

Podolny, J. M. (2001). Networks as the pipes and prisms of the market. American Journal of Sociology, 107: 33-60.

Revista Competencia Económica (1970), Buenos Aires, Argentina, (43).

Rhee, M. \& Valdez, M. (2009). Contextual factors surrounding reputation damage with potential implications for reputation repair. Academy of Management Review, 34(1):146-168.

Rinaldi, A. \& Vasta, M. (2005). The Structure of Italian Capitalism, 1952-1972: New Evidence Using the Interlocking Directorates Technique. Financial History Review, 2: 173-198.

Romero, L.A. (2009). La violencia en la historia argentina reciente: un estado de la cuestión, en Anne Pérotin-Dumon (dir.). Historizar el pasado vivo en América Latina (on-line).

Ross Schneider, B. (2004). Business Politics and the State in 20th Century Latin America. New York: Cambridge University Press. 
Rougier, M. (2004). Industria, finanzas e instituciones en la Argentina. La experiencia del Banco Nacional de Desarrollo. 1967-1976. Bernal: Universidad Nacional de Quilmes.

Salvaj, E. \& Ferraro, F. (2005), Las Redes de Propiedad y de Consejos de Administración del IBEX 35. en Los accionistas y el gobierno de la empresa. Análisis de la situación española. Edited by Joan Enric Ricart, Jose Luis Alvarez and Julia Gifra. Ediciones Deusto: 179-211, 179-211.

Sapelli, C. (2003), The political economics of Import substitution Industrialization, Economics Institute Working Paper No. 257, Santiago de Chile: PUC.

Scott, J. (2007). Social Network Analysis, a handbook. Second Edition. London, UK: Sage Publications.

Shropshire, C. (2010). The Role of the Interlocking Director and Board Receptivity in the Diffusion of Practices. Academy of Management Review, 35 (2): 246-264.

Silva, F., Majluf, N. \& Paredes, R. (2006). Family ties, interlocking directors and performance of business groups in emerging countries: The case of Chile. Journal of Business Research 59: 315-321.

Skidmore, T. \& Smith, P. (2001). Modern Latin America. New York: Oxford University Press.

Solimano, A. (2002). Political violence and economic development in Latin America: issues and evidence, Serie macroeconómica del desarrollo, Santiago de Chile: CEPAL.

Sourrouille, J. (1976). The Impact of Transnational Enterprises on Employment and Income: The Case of Argentina, World Employment Program Research, Working Papers, Geneva: International Labor Office.

Sourrouille, J., Kosacoff, B. \& Lucangeli, J. (1985). Transnacionalización y política económica en la Argentina, Buenos Aires: CEAL/CEPAL.

Stokman, F., Ziegler, R. \& Scott, J. (1985). Networks of Corporate Power: A Comparative Analysis of Ten Countries. Cambridge: Polity Press.

Tokman, V. (1973). Concentration of economic power in Argentina. World Development 1 (10): 33-41.

Universidad Argentina de la Empresa \& Instituto de Investigaciones Bancarias y Monetarias (1973). Bancar Nro. 2, Buenos Aires: UAE

Useem, M. (1984), The inner circle. New York, Oxford University Press. 
Wasserman, S. \& Faust, K. (1994). Social Network Analysis. Methods and applications. Cambridge. UK: Cambridge University Press.

Windolf, P. (2002). Corporate Networks in Europe and the United States, Oxford: Oxford University Press.

Windolf, P. (2008). Coordination and control in corporate networks: United States and Germany in comparison, 1896-1938. European Sociological Review, 25(4): 443-457.

Zeitlin, M. \& Ratcliff, R. (1988). Landlords \& Capitalists: The Dominant Class of Chile. Princeton: Princeton University Press. 


\section{Appendix}

\begin{tabular}{|c|c|}
\hline Corporation & Controlling Proprietary Interests \\
\hline Pacific Steel Co. (CAP) & Corfo and Amortization Institute \\
\hline Paper \& Cardboard Mfg. Co. & Matte family and associates \\
\hline "El Melon" Industrial Enterprises & Cortés family and associates \\
\hline South America Steamship Co. (CSAV) & Vial and MacAuliffe families and associates \\
\hline Sumar Products & Sumar family \\
\hline United Breweries Co. & Edwards family and associates \\
\hline General Industries Electricity Co. & Claro family and associates \\
\hline Petroleum Company of Chile (COPEC) & None disclosed \\
\hline Tierra del Fuego Cattle & Braun-Menendez family and associates \\
\hline Lota-Schwager Coal & $\begin{array}{l}\text { Cousiño and Claude families with Cortés } \\
\text { family }\end{array}$ \\
\hline Mantos Blancos Mining Enterprise & Mauricio Hochschild and associates \\
\hline Yarur Chilean Cotton Products & Yarur Banna family \\
\hline Hirmas Cotton & Hirmas family \\
\hline The Industrial Co. (INDUS) & Edwards family and associates \\
\hline Copper Products (MADECO) & Simonetti family and associates \\
\hline Viña del Mar Sugar Refining Co. (CRAV) & Edwards and Claude family and associates \\
\hline Metal Mfg. (MADEMSA) & Simonetti family and associates \\
\hline Santiago Gas Consumers Co. (GASCO) & Claudio Troncoso and associates \\
\hline El Mercurio Journalism Enterprises & Edwards family \\
\hline "Pasaje Matte" Urban Rental Association & Matte family and associates \\
\hline Caupolican Textiles & Yarur Banna and Grace interests \\
\hline Glassware of Chile & $\begin{array}{l}\text { Corning PPG joint control with Cousiño y } \\
\text { Edwards }\end{array}$ \\
\hline National Distributing Co. (CODINA) & $\begin{array}{l}\text { Schmutzer family with Edwards and } \\
\text { Claude families }\end{array}$ \\
\hline $\begin{array}{l}\text { Penco National Ceramics Factory } \\
\text { (FANALOZA) }\end{array}$ & Díaz family and associates \\
\hline Enamelware Factory (FENSA) & Briones family and associates \\
\hline Zig-Zag Publishing Enterprises & Helfmann family and associates \\
\hline $\begin{array}{l}\text { Said Rayon and Chemicals Ind. } \\
\text { (RAYONSAID) }\end{array}$ & Said Family \\
\hline Bella Vista - Tomé Cloth Factory & Yarur Asfura and Grace interests \\
\hline Tomé National Fabrics & Furman family and associates \\
\hline Petroleum Navigation Corp. & Braun-Menéndez and Vial families \\
\hline Chile Interoceanic Navigation Co. & Braun-Menéndez family \\
\hline Progreso Textiles & Yarur Kazakia family \\
\hline Saavedra Benard & Bank of Chile \\
\hline Universo Printing \& Lithography & Helfmann family and associates \\
\hline Oruro Mining Co. & Mauricio Hochschild and associates \\
\hline Tamaya Mining Co. & Jointly by Corfo and private interests \\
\hline Coronel Shipping & Cousiño and Claude familias \\
\hline
\end{tabular}

Source: Zeitlin \& Ratcliff, 1988.

Table A1. Control of the Top 37 Non-financial Corporations in Chile, 1964-1966 


\begin{tabular}{|c|c|c|c|c|c|c|c|c|c|c|}
\hline \multirow{3}{*}{ Year } & \multicolumn{3}{|c|}{ Legal Authority } & \multicolumn{4}{c|}{ Sector } & \multicolumn{3}{c|}{ Country of Origin } \\
\cline { 2 - 11 } & $\begin{array}{c}\text { Act } \\
14222\end{array}$ & $\begin{array}{c}\text { Circulars } \\
2324 / 383 \\
1\end{array}$ & $\begin{array}{c}\text { Act } \\
14780\end{array}$ & $\begin{array}{c}\text { Transport } \\
\text { Equipment }\end{array}$ & $\begin{array}{c}\text { Chem. } \\
\text { Prod. }\end{array}$ & $\begin{array}{l}\text { Machin } \\
\text { ery }\end{array}$ & Other & U.S. & Germany & Others \\
\hline 1958 & - & 4.9 & 12.9 & 1.2 & 4.2 & 5.1 & 2.4 & 6.4 & 0.4 & 6.1 \\
\hline 1959 & - & - & 209.3 & 63.1 & 85.4 & 6.7 & 54.0 & 106.5 & 14.2 & 78.5 \\
\hline 1960 & - & - & 111.7 & 18.0 & 63.6 & 6.9 & 23.2 & 71.3 & 11.7 & 28.7 \\
\hline 1961 & - & - & 133.3 & 51.7 & 32.0 & 2.1 & 47.6 & 74.5 & 1.5 & 57.3 \\
\hline 1962 & - & - & 85.7 & 1.6 & 11.6 & 5.4 & 67.2 & 70.1 & 2.7 & 12.9 \\
\hline 1963 & - & - & 34.6 & 14.4 & 1.3 & 7.2 & 11.7 & 15.7 & 1.0 & 17.9 \\
\hline 1964 & - & - & 33.8 & 20.7 & 1.1 & 6.6 & 5.4 & 0.5 & 1.9 & 21.3 \\
\hline 1965 & - & - & 6.3 & 0.3 & 0.4 & 2.4 & 3.3 & 2.0 & 0.7 & 2.6 \\
\hline 1966 & - & - & 2.5 & 0.3 & 0.2 & 0.3 & 1.7 & 0.8 & 0.4 & 1.3 \\
\hline 1967 & - & - & 13.1 & 9.2 & 0.7 & 0.1 & 3.0 & 9.9 & 0.8 & 2.9 \\
\hline 1968 & - & - & 31.5 & 13.1 & 6.6 & 3.7 & 8.1 & 20.9 & 2.0 & 8.6 \\
\hline 1969 & - & - & 59.1 & 5.2 & 46.2 & 2.7 & 5.0 & 12.0 & 0.8 & 46.3 \\
\hline 1970 & - & - & 9.8 & - & 0.1 & - & 9.6 & 0.2 & 1.6 & 8.0 \\
\hline
\end{tabular}

Source: Ministry of Economy, Economic Report, several issues, and Decrees of the National Executive Branch. quoted in Sourrouille, Juan (1976) "The Impact of Transnational Enterprises on Employment and Income: The Case of Argentina", World Employment Program Research, Working Papers, Geneva: International Labor Office, p. 22.

Table A2. Authorizations for foreign capital investments (in US\$ millions)

\section{Data collection process}

We used a sample of the largest Argentine and Chilean firms in the late 1960s. We identified the largest firms in Chile based on several criteria (Chile Economic News, published by CORFO, does not list the largest Chilean firms in 1967-1973). First, from El libro de las 91 (AAVV, 1972), we identified 91 monopolistic firms operating in Chile in the early 1970s. We collected information on 63 of these firms; we also used that list to catalog 65 of the top 100 firms by annual traded value in 1969, as registered on the Santiago Stock Exchange. We included 10 of the largest stateowned firms and the 25 largest banks in 1969, listed by Behrens Fuchs (1985). Our final database thus featured 165 Chilean firms. We gathered information about their board composition from Chile's Superintendency of Banks and Financial Institutions, Superintendency of Securities and Insurance, and annual reports. In Argentina, we collected information on 82 large firms by sales, according to Competencia Económica (1970) magazine's ranking. We also gathered information on Argentine companies' board composition in 1971 from Guía de Sociedades Anónimas (1972). From the ranking provided by Bancar (1973), we extracted information on 33 of the 50 largest Argentine banks in the early 1970s, including their syndics. Table A3 records the number of companies in every industry, listed with their respective ownership scheme. 


\begin{tabular}{|c|c|c|c|c|c|c|c|c|c|c|c|c|c|c|c|c|}
\hline & \multicolumn{16}{|c|}{ Ownership } \\
\hline & \multicolumn{2}{|c|}{$\begin{array}{c}\text { Local } \\
\text { families }\end{array}$} & \multicolumn{2}{|c|}{$\begin{array}{l}\text { State- } \\
\text { owned }\end{array}$} & \multicolumn{2}{|c|}{$\begin{array}{c}\text { Other } \\
\text { domestic }\end{array}$} & \multicolumn{2}{|c|}{ MNCS } & \multicolumn{2}{|c|}{$\begin{array}{c}\text { Local } \\
\text { families - } \\
\text { MNCS }\end{array}$} & \multicolumn{2}{|c|}{$\begin{array}{c}\text { Other } \\
\text { domestic } \\
\text { - MNCs }\end{array}$} & \multicolumn{2}{|c|}{\begin{tabular}{|c|} 
State- \\
owned - \\
other \\
domestic \\
\end{tabular}} & \multicolumn{2}{|c|}{ Total } \\
\hline & \begin{tabular}{|c} 
Argen \\
tinan
\end{tabular} & Chile & $\begin{array}{c}\text { Argen } \\
\text { tina }\end{array}$ & Chile & $\begin{array}{c}\text { Argen } \\
\text { tina }\end{array}$ & Chile & $\begin{array}{c}\text { Argen } \\
\text { tina }\end{array}$ & Chile & $\begin{array}{c}\text { Argen } \\
\text { tina }\end{array}$ & Chile & $\begin{array}{c}\text { Argen } \\
\text { tina }\end{array}$ & Chile & \begin{tabular}{|c} 
Argen \\
tina
\end{tabular} & Chile & $\begin{array}{c}\text { Argen } \\
\text { tinan }\end{array}$ & Chile \\
\hline $\begin{array}{c}\text { Manufacturi } \\
\text { ng }\end{array}$ & 22 & 38 & 2 & 7 & 5 & 17 & 41 & 11 & 4 & 2 & 1 & 0 & 2 & 1 & 77 & 76 \\
\hline $\begin{array}{c}\text { Financial } \\
\text { services }\end{array}$ & 9 & 14 & 4 & 3 & 9 & 5 & 6 & 2 & 0 & 0 & 0 & 0 & 5 & 0 & 33 & 25 \\
\hline Insurance & 0 & 7 & 0 & 0 & 0 & 5 & 0 & 2 & 0 & 0 & 0 & 0 & 0 & 0 & 0 & 14 \\
\hline Utilities & 0 & 1 & 1 & 2 & 0 & 3 & 0 & 3 & 0 & 0 & 0 & 0 & 0 & 1 & 1 & 10 \\
\hline Mining & 0 & 1 & 0 & 1 & 0 & 3 & 1 & 2 & 0 & 0 & 0 & 0 & 0 & 0 & 1 & 7 \\
\hline $\begin{array}{c}\text { Transportati } \\
\text { on }\end{array}$ & 0 & 4 & 1 & 0 & 0 & 1 & 0 & 0 & 0 & 0 & 0 & 0 & 0 & 0 & 1 & 5 \\
\hline $\begin{array}{c}\text { Commoditie } \\
\mathrm{s}\end{array}$ & 0 & 7 & 0 & 0 & 0 & 1 & 1 & 2 & 0 & 0 & 0 & 0 & 0 & 0 & 1 & 10 \\
\hline Services & 1 & 5 & 0 & 0 & 0 & 0 & 6 & 1 & 4 & 0 & 0 & 0 & 0 & 0 & 2 & 15 \\
\hline Holdings & 0 & 3 & 0 & 0 & 0 & 0 & 0 & 0 & 0 & 0 & 0 & 0 & 0 & 0 & 0 & 3 \\
\hline Total & 32 & 80 & 8 & 13 & 14 & 41 & 50 & 27 & 4 & 2 & 1 & 0 & 7 & 2 & 116 & 165 \\
\hline
\end{tabular}

Table A3. Sample data

\section{Method}

We employed social network analysis to test our hypotheses, studying board networks connected by directors serving at Chile's and Argentina's largest companies, using UCINET's software (Borgatti, Everett, \& Freeman, 2002). The first step in our comparative analysis was a review of their graphical representations. We used Netdraw (network visualization package bundled with UCINET).

Next, we calculated and compared networks' structural measurements (see Table 1 and its description). Thirdly, we identified the most central actors or those with high dominance and social capital in the network. A number of measures can capture board centrality, including degree centrality, eigenvector, and betweenness centrality (Scott, 2007; Wasserman \& Faust, 1994). This study encompasses three centralities (though we have only presented the results for betweenness centrality due to the high correlation linking all three). Degree centrality refers to the number of boards to which one board is connected, while eigenvector centrality offers a variant of the simple degree. Based on this measure, a node is more central if the nodes to which it connects are also central (Bonacich, 1987). Hence, a board connected to many well-connected boards earns a high score, but a board connected only to near-isolates gets a lower score, even if it boasts high degree 
centrality. Betweenness centrality suggests that a board lying on communication paths can control communication flows and is, therefore, important. Betweenness centrality counts the number of geodesic paths between $i$ and $k$ on which board $j$ resides; a geodesic line is the shortest path between a pair of boards (Wasserman \& Faust, 1994). Thus, this measures indexes the extent to which a board facilitates the flow of information across the corporate elite and "brokers" relationships in the network.

Finally, to investigate differences separating centrality measurements for financial versus nonfinancial institutions, foreign-owned versus local firms, and firms owned by business groups versus non-business group-owned firms, we used the MannWhitney test. We employed this nonparametric test because the distribution of the centrality measurements was non-normal (Hollander \& Wolfe, 1999).

\begin{tabular}{|c|c|c|c|c|c|c|c|}
\hline \multicolumn{4}{|c|}{ Argentina } & \multicolumn{4}{|c|}{ Chile } \\
\hline $\begin{array}{l}\text { Director's } \\
\text { name }\end{array}$ & $\begin{array}{l}\text { Bet. } \\
\text { Cent. }\end{array}$ & Profession & Government official & $\begin{array}{l}\text { Director's } \\
\text { name }\end{array}$ & $\begin{array}{l}\text { Bet. } \\
\text { Cent. }\end{array}$ & Profession & Government official \\
\hline Diego Arguello & 0.067 & NDA & NDA & \begin{tabular}{|l|} 
Agustin \\
Edwards \\
Eastman
\end{tabular} & 0.031 & $\begin{array}{l}\text { Businessma } \\
\text { n }\end{array}$ & No \\
\hline $\begin{array}{l}\text { Jorge Eduardo } \\
\text { O'Farrell }\end{array}$ & 0.075 & Lawyer & No & \begin{tabular}{|l} 
Salustio \\
Prieto \\
Calvo
\end{tabular} & 0.032 & $\begin{array}{l}\text { Businessma } \\
n\end{array}$ & No \\
\hline \begin{tabular}{|l|} 
Damian Beccar \\
Varela
\end{tabular} & 0.084 & Lawyer & No & \begin{tabular}{|l} 
Edgardo \\
Cruz \\
Plaza
\end{tabular} & 0.033 & Engineer & $\begin{array}{l}\text { Superintendent of } \\
\text { Electricity Services }\end{array}$ \\
\hline $\begin{array}{l}\text { Enrique } \\
\text { Steggman }\end{array}$ & 0.084 & Businessman & $\begin{array}{l}\text { National } \\
\text { Undersecretary of } \\
\text { Industry and Mining } \\
\text { (1962); Mineral } \\
\text { Trade Chairman } \\
(1962)\end{array}$ & \begin{tabular}{|l} 
Recaredo \\
Ossa \\
Undurraga
\end{tabular} & 0.033 & $\begin{array}{l}\text { Businessma } \\
\text { n }\end{array}$ & No \\
\hline Jose Negri & 0.089 & Engineer & No & $\begin{array}{l}\text { Jorge Ross } \\
\text { Ossa }\end{array}$ & 0.034 & $\begin{array}{l}\text { Chemical } \\
\text { Engineer/ } \\
\text { Businessma } \\
\mathrm{n}\end{array}$ & No \\
\hline \begin{tabular}{|l|} 
Jorge Nicolas \\
Zaefferer Toro
\end{tabular} & 0.089 & Lawyer & $\begin{array}{l}\text { Undersecretary of } \\
\text { Economy (1959- } \\
1962) \text { / Secretary } \\
\text { of Commerce } 1962\end{array}$ & $\begin{array}{l}\text { Aurelio } \\
\text { Fernandez } \\
\text { Barros }\end{array}$ & 0.036 & Lawyer & No \\
\hline $\begin{array}{l}\text { Emilio } \\
\text { Gagliardi }\end{array}$ & 0.095 & Engineer & NDA & $\begin{array}{l}\text { Jorge Silva } \\
\text { Romo }\end{array}$ & 0.036 & Lawyer & No \\
\hline Silvio Gagliardi & 0.095 & Engineer & $\begin{array}{l}\text { General Director of } \\
\text { State Supplies, } \\
\text { Director of Forestry } \\
\text { Investments }\end{array}$ & $\begin{array}{l}\text { Anacleto } \\
\text { Angelini } \\
\text { Fabbri }\end{array}$ & 0.04 & $\begin{array}{l}\text { Businessma } \\
\text { n }\end{array}$ & No \\
\hline $\begin{array}{l}\text { Rodolfo } \\
\text { Moltedo }\end{array}$ & 0.108 & Lawyer & No & $\begin{array}{l}\text { Felix Huttner } \\
\text { Skall }\end{array}$ & 0.04 & NDA & NDA \\
\hline
\end{tabular}




\begin{tabular}{|c|c|c|c|c|c|c|c|}
\hline Alberto Lopez & 0.126 & $\begin{array}{l}\text { Certified } \\
\text { Public } \\
\text { Accountant }\end{array}$ & $\begin{array}{l}\text { General Director of } \\
\text { Credit Taxes }\end{array}$ & $\begin{array}{l}\text { Jorge Raby } \\
\text { Birrel }\end{array}$ & 0.041 & Lawyer & No \\
\hline $\begin{array}{l}\text { Carlos Alberto } \\
\text { Juni }\end{array}$ & 0.126 & Lawyer & $\begin{array}{l}\text { Secretary of State; } \\
\text { Former minister }\end{array}$ & \begin{tabular}{|l} 
Ernesto \\
Barros \\
Jarpa
\end{tabular} & 0.045 & Lawyer & $\begin{array}{l}\text { Minister of Foreign } \\
\text { Affairs } \\
(1921 / 1926 / 1942)\end{array}$ \\
\hline Carlos Dietl & 0.129 & Engineer & no & \begin{tabular}{|l} 
Manuel \\
Zanartu \\
Campino
\end{tabular} & 0.045 & $\begin{array}{l}\text { Engineer/ } \\
\text { Businessma } \\
\text { n }\end{array}$ & No \\
\hline \begin{tabular}{|l|} 
Andrea \\
Wynveldt
\end{tabular} & 0.151 & $\begin{array}{l}\text { Certified } \\
\text { Public } \\
\text { Accountant }\end{array}$ & no & \begin{tabular}{|l} 
Vicente \\
Izquierdo \\
Besa \\
\end{tabular} & 0.048 & \begin{tabular}{|l|} 
Engineer/ \\
Businessma \\
n
\end{tabular} & No \\
\hline \begin{tabular}{|l|} 
Eduardo Maria \\
Huergo
\end{tabular} & 0.156 & Engineer & $\begin{array}{l}\text { Minister of Public } \\
\text { Works and National } \\
\text { Industry } \\
\text { Intervention in } \\
\text { Córdoba }\end{array}$ & $\begin{array}{l}\text { Pablo } \\
\text { Aldunate } \\
\text { Phillips }\end{array}$ & 0.069 & Lawyer & \begin{tabular}{|l} 
State \\
Representative \\
$(1957-1961)$
\end{tabular} \\
\hline Jorge Decarli & 0.17 & NDA & NDA & $\begin{array}{l}\text { Hector Braun } \\
\text { Guevara }\end{array}$ & 0.07 & $\begin{array}{l}\text { Businessma } \\
\mathrm{n}\end{array}$ & No \\
\hline $\begin{array}{l}\text { Juan Pedro } \\
\text { Thibaud }\end{array}$ & 0.214 & Engineer & $\begin{array}{l}\text { Undersecretary of } \\
\text { Energy (1966); } \\
\text { Undersecretary of } \\
\text { Mining and Oil } \\
\text { (1967) }\end{array}$ & \begin{tabular}{|l} 
Arturo \\
Quiroz \\
Fitzsimmons
\end{tabular} & 0.084 & $\begin{array}{l}\text { Engineer/ } \\
\text { Businessma } \\
\mathrm{n}\end{array}$ & No \\
\hline Gaston Texier & 0.234 & Businessman & No & $\begin{array}{l}\text { Guillermo } \\
\text { Correa } \\
\text { Fuenzalida }\end{array}$ & 0.091 & Lawyer & $\begin{array}{l}\text { Minister (1937- } \\
1938) ; \text { Minister of } \\
\text { Justice(1946- } \\
\text { 1947); } \\
\text { Representative of } \\
\text { State (1930-1934) }\end{array}$ \\
\hline Alfredo Lisdero & 0.254 & $\begin{array}{l}\text { Certified } \\
\text { Public } \\
\text { Accountant }\end{array}$ & $\begin{array}{l}\text { YPF Advisor (1940- } \\
\text { 46) and UIA } \\
\text { Advisor (1940-52) }\end{array}$ & $\begin{array}{l}\text { Walter } \\
\text { Muller } \\
\text { Hess }\end{array}$ & 0.11 & \begin{tabular}{|l} 
Businessma \\
$n$
\end{tabular} & $\begin{array}{l}\text { Chilean } \\
\text { Ambassador in USA } \\
\text { Turing Cuba-US } \\
\text { crisis }\end{array}$ \\
\hline $\begin{array}{l}\text { Eduardo } \\
\text { Johnson }\end{array}$ & 0.318 & $\begin{array}{l}\text { Certified } \\
\text { Public } \\
\text { Accountant }\end{array}$ & No & $\begin{array}{l}\text { Patricio } \\
\text { Garcia } \\
\text { Vela }\end{array}$ & 0.118 & $\begin{array}{l}\text { Businessma } \\
\text { n }\end{array}$ & No \\
\hline $\begin{array}{l}\text { Enrique } \\
\text { Roberts }\end{array}$ & 0.441 & Businessman & No & $\begin{array}{l}\text { Eliodoro } \\
\text { Matte } \\
\text { Ossa }\end{array}$ & 0.231 & $\begin{array}{l}\text { Businessma } \\
\text { n }\end{array}$ & No \\
\hline
\end{tabular}

Table A4. Top Linchpin Directors 